ЩОДО ПРОБЛЕМИ ВДОСКОНАЛЕННЯ МЕХАНІЗМУ ДЕРЖАВНОГО УПРАВЛІННЯ РОЗВИТКОМ ІННОВАЦІЙНОГО КАПІТАЛУ ДЛЯ ГАЛУЗІ ТУРИЗМУ ПОСТІНДУСТРІАЛЬНОГО СУСПІЛЬСТВА

\title{
TO THE PROBLEM OF IMPROVING THE MECHANISM OF STATE GOVERNANCE DEVELOPMENT OF INNOVATIVE CAPITAL FOR THE POSTINDUSTRIAL SUSTAINABLE TOURISM
}

у статті висвітлено проблему вдосконалення механізму державного управління розвитком інноваційного капіталу для галузі туризму постіндустріального суспільства. Розглянуто розуміння вирішення цієї проблеми на основі управління розбудовою та фрункціонуванням інноваційних освітніх структур на базі вищої школи. Цей підхід ґрунтується на теоретичних розробках моделей державного управління системою фахової підготовки для індустріального й постіндустріального виробництва. Представлено відмінності в співвідношенні розвитку секторів економіки для суспільств з індустріальним і постіндустріальним виробництвом. Указано на соціальну адекватність певних моделей неперервної освіти для індустріального та постіндустріального виробництва. Показано роль вищої освіти в підготовці фрахівців для кожного $з$ виробництв. Звернено увагу на роль вищоі регіональної освіти в підготовці фрахівців із туризму з інноваційним мисленням та інноваційною культурою для економіки. Відзначено роль інноваційного капіталу для зростання економіки й науково-технічного прогресу постіндустріального суспільства. Зазначено необхідність змін у професійній підготовці фахівців з туризму під час переходу країни до постіндустріального виробництва. Надано сутність людського капіталу. Представлено розуміння інноваційного капіталу та розкрито його складники. Відзначено необхідність інноваційної освітньої регіональної інфраструктури для створення інноваційного простору фрахової підготовки. Надано основні напрями вдосконалення механізму державного управління розвитком інноваційного капіталу для галузі туризму. До напрямів удосконалення державного управління розвитком інноваційного капіталу для галузі туризму зазначено впровадження зарубіжного досвіду країн із розвиненою туріндустрією. Також указано створення інноваційної освітньої інфрраструктури на базі університетів для розвитку й реалізації підприємницького потенціалу фрахівців з туризму. Відзначено необхідність надання консультативних послуг для студентів для реалізації власноі справи - бізнес-проекту - в умовах інноваційної освітньої інфрраструктури.

Ключові слова: механізм державного управління, напрями вдосконалення державного управління, інноваційна освітня інфраструк- тура, вища школа, інноваційний капітал, фахівці з туризму.

The article deals with the problem of improving the mechanism of state management of the development of innovative capital for the tourism industry of post-industrial society. The understanding of the solution of this problem on the basis of management of development and functioning of innovative educational structures on the basis of higher education is shown. This approach is based on the theoretical development of models of state management of the system of professional training for industrial and post-industrial production. Differences in the ratio of development of economic sectors for societies with industrial and post-industrial production are presented. The social adequacy of certain models of continuous education for industrial and post-industrial production is indicated. The role of higher education in the training of specialists for each industry is shown. Attention is drawn to the role of higher regional education in training tourism professionals with innovative thinking and innovative culture for the economy. The role of innovation capital for the growth of economy and scientific and technological progress of post-industrial society is noted. The necessity of changes in the professional training of tourism specialists in the transition of the country to post-industrial production is noted. The essence of human capital is given. Understanding of innovative capital is presented and its components are revealed. The need for innovative educational regional infrastructure to create an innovative space for professional training was noted. The basic directions of improvement of the mechanism of state management of development of innovative capital for the branch of tourism are given. The directions of improvement of the state management of the development of innovative capital for the tourism industry include introduction of foreign experience of countries with developed tourism industry. Also included is the creation of an innovative educational infrastructure based on universities to develop and realize the entrepreneurial potential of tourism professionals. The necessity of providing advisory services for students for realization of their own business - business project in the conditions of innovative educational infrastructure was noted.

Key words: mechanism of public administration, directions of improvement of public administration, innovative educational infrastructure, high school, innovative capital, specialists in tourism.
Постановка проблеми в загальному вигляді. Згідно з оцінками Всесвітнього банку, фізичний капітал у сучасній економіці формує $16 \%$ загального багатства кожної країни, природний - 20\%, а людський капітал - 64\%. у Японії та Германії частка людського капіталу становить до 80\% національного багатства.
Значення інноваційного капіталу як складника неуречевленого капіталу для країни проявляється в його ролі як стратегічного ресурсу динамічного зростання економіки й науково-технічного прогресу постіндустріального суспільства. Тому проблема вдосконалення механізму державного управління 
розвитком інноваційного капіталу для галузі туризму як провідного сектору нової економіки потребує подальшого вивчення.

Аналіз останніх досліджень і публікацій. У наукових працях Гаєвської, Н. Діденко, О. Жабенко, Н. Колісниченко, В. Лобас, В. Лугового, С. Майбороди, Г. Огаренко, В. Токаревої, О. Тягушевої, О. Черниш та інших аналізувалися проблеми державного управління системою освіти, її окремими складниками, менеджмент-освітою, регіональною освітою, процесом навчання, інноваційними університетськими комплексами, визначалися особливості й тенденції управління освітою тощо. Багатьма сучасними дослідниками аналізувалася проблема людського капіталу, зокрема В. Антонюк з'ясувала складники неуречевленого капіталу; Л. Янковська виокремила зовнішні чинники, що впливають на величину та якість людського капіталу; О. Любчук розробила структуру неуречевленого капіталу для постіндустріального суспільства і подала розуміння інноваційного капіталу та його складників. Проблема «інноваційної якості» людських ресурсів досліджувалася в роботах Л. Семів, Р. Семів, С. Шульц. Значення сформованості інноваційної культури для розбудови інноваційного регіонального простору з'ясовувалося В. Токаревою, складники інноваційного регіонального освітнього простору та їх характеристики розкривалися в дослідженні М. Бачинської. Стратегічні засади розвитку підприємництва в Україні та вияв і розвиток його підприємницького потенціалу розробляли Н. Бєльська, О. Любчук, С. Поважний, В. Цап.

Виділення не вирішених частин загальної проблеми. Перехід від індустріального до постіндустріального суспільства потребує створення умов у системі фахової підготовки у вищій школі для виявлення та подальшого розвитку інноваційного складника неуречевленого капіталу для соціально-економічного розвитку кожного регіону та країни загалом. Туріндустрія входить у ТОП-5 галузей, що приносять найбільші доходи у світі. За прибутковістю вона випереджає навіть вугільну промисловість. Туризм для сьогодення $\epsilon$ одним із найбільш перспективних напрямів розбудови як постіндустріального суспільства, так і ринкової економіки. Незважаючи на те що сучасний стан розвитку туристичної галузі супроводжується активізацією підприємницької активності у сфері туризму, міжнародною конкуренцією, зміною в потребах туристів, проблема відповідності розвитку туристичної галузі в Україні світовим тенденціям $€$ не вирішеною. Тому дослідження про- блеми вдосконалення механізму державного управління розвитком інноваційного капіталу для галузі туризму постіндустріального суспільства є затребуваним.

Мета статті полягає в з'ясуванні напрямів удосконалення механізму державного управління розвитком інноваційного капіталу для галузі туризму постіндустріального виробництва.

Виклад основного матеріалу. Для індустріального суспільства, як констатує О. Черниш, зайнятість населення в секторах економіки становить 20:50:30, тобто 20\% населення зайнято в сільському господарстві й добувній промисловості - первинному секторі економіки, 50\% населення зайнято в обробній промисловості - вторинному секторі економіки, 30\% населення зайнято у сфері послуг - третинному секторі економіки; для постіндустріального суспільства зайнятість населення в секторах економіки становить 10:10:80, тобто $10 \%$ населення зайнято в сільському господарстві та добувній промисловості - первинному секторі економіки, 10\% населення зайнято в обробній промисловості - вторинному секторі економіки, 80\% населення зайнято у сфері послуг - третинному секторі економіки [3].

Для індустріального виробництва соціально-адекватною була знаннєво-орієнтована модель неперервної освіти, вища освіта якої була елітарною, надавала якісні фундаментальні знання, що забезпечували високий професіоналізм протягом усієї життєдіяльності, а також соціальний і матеріальний статус у суспільстві. Для постіндустріального виробництва соціально-адекватною $€$ модель неперервної освіти, яка базується на суб'єкт-суб'єктній парадигмі, вища освіта якої стає масовою й високий статус у суспільстві забезпечується особистісними зусиллями в навчанні протягом життя, де вища освіта $€$ тільки необхідним етапом у професійному становленні фахівця, в розкритті його творчого та інноваційного потенціалів завдяки становленню вищої освіти елементом інноваційної освітньої інфраструктури, інноваційного освітнього простору [2].

В умовах переходу до постіндустріального суспільства на конкурентоздатність секторів економіки країни, зокрема туризму, впливає рівень розвитку регіональної системи освіти, її спроможність навчати та підготувати кадри з інноваційним мисленням та інноваційною культурою.

Людський капітал, згідно з дослідженнями Л. Янковської, - це та частина людського потенціалу, яким володіє підприємство, регіон, 
держава; це те, що насправді використовується в господарських процесах, тоді як потенціал - це те, чим потенційно володіє структура (регіон, держава). Основою людського капіталу в регіоні є людські ресурси, якість та обсяг яких визначається наявністю в них робочої сили. На величину і якість людського капіталу впливають зовнішні чинники - економічна й соціальна політика держави, рівень розвитку економіки, демографічні процеси тощо [4].

Під інноваційним капіталом суспільства «знань» розуміємо інноваційний потенціал суспільства, який застосовується в процесі економічного розвитку, до складників якого належать здатності особистості до інноваційної діяльності, до практичного впровадження інновацій; організаційно-лідерський потенціал; підприємницький потенціал; неформалізовані знання, уміння, навички, здібності (таланти); фізичне та психічне здоров'я; соціально-психологічні характеристики людини: моральні цінності, соціальні норми, загальна культура, мобільність; соціальні відносини: соціальна взаємодія, соціальна справедливість; спрямованість (мотивація) на інноваційну діяльність; упроваджені результати інноваційної праці в економіці: нові товари та послуги (на основі наукових розробок), організація їх виробництва. Інноваційний капітал як складник неуречевленого капіталу постіндустріального суспільства повинен включати до свого складу такі складники:

- спрямованість (мотивація) на інноваційну діяльність;

- уміння вчитися нового або створювати його в стабільних і нестабільних соціально-економічних умовах упродовж життя;

- здатність до інноваційної діяльності, здатність до практичного впровадження інновацій, організаційно-лідерський потенціал;

- упроваджені результати інтелектуальної праці в економіці: нові товари та послуги (на основі наукових розробок), організацію їх виробництва [2].

Інноваційний капітал включає до свого складу також спільні елементи з людським, інтелектуальним і соціальним капіталами. Як зазначає В. Антонюк, інтеграція між різними формами неуречевленого капіталу забезпечується не тільки тим, що вони мають спільні елементи, а і їх тісною взаємодією та взаємним впливом. Особливістю неуречевленого капіталу є його збільшення, а не зменшення під час використання, невичерпність, що впливає на становлення його основним чинником економічногорозвиткутасоціальногопрогресу [1].

Для становлення інноваційного освітнього простору необхідним $є$ впровадження інно- вацій як у систему неперервної освіти регіону, в підготовку державних службовців та управлінських кадрів, так і в процес розбудови ефективної співпраці між центральними й регіональними органами управління та освітою (університетами) як суб'єктом інноваційної освітньої діяльності. Розвиток інноваційного простору фахової підготовки передбачає подальшу розбудову інноваційної освітньої регіональної інфраструктури (бізнес-інкубаторів, інноваційнихцентрів, регіональнихнауковоосвітніх комплексів, технопарків тощо) як складника інноваційної інфраструктури регіону.

До основних напрямів удосконалення механізму державного управління розвитком інноваційного капіталу для галузі туризму варто зарахувати такі:

- визначення на основі теоретичного аналізу найбільш ефективних моделей державного управління фаховою підготовкою інноваційних кадрів для галузі туризму в розвинених країнах світу та їх упровадження;

- створення координаційних органів, до складу яких входили б представники головного управління промисловості й розвитку інфраструктури, професійних асоціацій роботодавців, ради ректорів регіону, громадських організацій, студентського самоуправління вищих навчальних закладів, регіонального фонду підтримки підприємництва для розроблення й підписання угод про партнерство в підготовці затребуваних кадрів, підвищення кваліфікації працівників підприємств на базі вишів; визначення перспектив випереджаючої підготовки спеціалістів; розроблення регіональних проектів; сприяння підготовці затребуваних висококваліфікованих спеціалістів;

- набуття університетамистатусуінноваційних науково-освітньо-промислових комплексів, регіональних методичних центрів освіти, науки й культури, що розробляють регіональну тематику на замовлення органів державної влади й бізнесових регіональних структур;

- створення на базі університетів інноваційного середовища регіону: технопарків, бізнес-інкубаторів, інноваційних виробництв на базі окремих вишів, створення експериментальних цехів, заводів, малосерійних наукоємних виробництв з виходом на ринок наукоємної продукції, інших суб'єктів підприємницької діяльності, що надають підготовку до підприємницької діяльності та здійснюють кадрове, правове, психологічне, маркетингове, інвестиційне забезпечення й супровід інноваційної діяльності;

- вихід національної системи вищої освіти з підготовки фахівців з туризму на ринок світових освітніх послуг, поглиблення міжнарод- 
ної співпраці, розширення участі навчальних закладів, викладачів і студентів, наукових працівників у проектах міжнародних організацій і співтовариств;

- підготовка фахівців зі сформованою інноваційною культурою, громадянською, особистісними та соціальними компетенціями, які мають фундаментальні наукові знання, вміють самостійно здобувати необхідну інформацію й на основі засвоєних методик наукового дослідження перетворювати її на інновації для стратегічного вирішення актуальних суспільних проблем, здатних адаптуватися до життєдіяльності в нестабільних, мінливих соціально-економічних умовах, що передбачає підготовку випускників вищої школи не до конкретного робочого місця, а до роботи в певній галузі, до широкої участі в трудовій діяльності;

- підвищення якості фахової підготовки інноваційних кадрів для галузі туризму на основі вияву, підтримки та розвитку здібностей і талантів, підприємницького потенціалу в студентської молоді;

- упровадження наукових розробок щодо формування вміння вчитися впродовж життя в систему формальної освіти для розбудови інформального складника неперервної освіти;

- сприяння розбудові інноваційної освітньої інфраструктури на базі університетів для розвитку й реалізації підприємницького потенціалу майбутніх фахівців з туризму;

- надання необхідних консультативних послуг для максимального наближення випускників в умовах інноваційної освітньої інфраструктури до реалізації власної справи бізнес-проекту - після закінчення навчального закладу;

- створення бізнес-інкубатору як громадської організації на базі вищої школи - структури, яка не тільки сприяє фахівцям із туризму в їхньому працевлаштуванні, а й поєднує теоретичну і практичну інноваційну підготовку, дає змогу кардинально перебудувати програми підготовок спеціалістів у сфері обслуговування та наблизити їх до реальних умов існування в нестабільні кризові періоди розвитку економіки, вирішувати стратегічне завдання підвищити якість підготовки інноваційних кадрів для розвитку малого й середнього бізнесу в регіоні.

Висновки. Отже, аналіз результатів проведених досліджень показав, що до інноваційних підходів, затребуваних у підготовці інноваційних кадрів для галузі туризму, варто зарахувати перебудову освітньо-професійного простору вищого навчального закладу в складник інноваційної освітньої інфраструктури регіону. Це стає можливим завдяки створенню та функціонуванню інноваційної освітньої інфраструктури в регіоні - громадської організації - міського бізнес-інкубатору на базі вищого навчального закладу, державно-громадське управління якої сприяє виконанню інноваційної освітньої функції - підготовці студентів спеціальності «Туризм» як соціальних інноваторів для економіки регіону.

\section{ЛІТЕРАТУРА:}

1. Антонюк В.П. Формування та використання людського капіталу в Україні: соціально-економічна оцінка та забезпечення розвитку : монографрія. Донецьк : Ін-т економіки промисловості НАН України, 2007. $348 \mathrm{c.}$

2. Любчук О.К. Теоретико-методологічні засади державного управління неперервною освітою в Україні та її регіонах : монографрія. Донецьк : СПД Куприянов, 2010. 406 с.

3. Черниш О.І. Теоретико-методологічні засади формування нових механізмів державного регулювання в ссрері соціально значимих послуг : дис. ... докт. наук 3 держ. управління : 25.00.02. Донецьк, 2005. $433 \mathrm{c}$.

4. Янковська Л.А Формування освітньо-фрахового потенціалу в системі соціально-економічного розвитку регіону : авторефр. дис. ... докт. екон. наук : 08.00.07 «Демографрія, економіка праці, соціальна економіка і політика». Львів, 2008. 49 с. 